\title{
Pengembangan Media Pembelajaran (Online) Berbantuan Aplikasi Kahoot Dan Komik Strip Dalam Upaya Meningkatkan Nilai Kognitif Siswa Kelas VIII SMPK ST. Fransiskus Asisi Samarinda
}

\author{
Nuryanti Purwanti ${ }^{1}$, Elsje Theodora Maasawet ${ }^{2}$, Vandalita M. M. Rambitan \\ Program Magister Pendidikan Biologi FKIP Universitas Mulawarman,
}

\begin{abstract}
The research was aimed to know the early diagnose toward students learning ability and the process condition of teaching and learning which were basis of the development science media learning which capable to increase cognitive learning value of students grade VIII SMPK. The purpose of research were: (1) to assist the lack of accomodation of earlier media learning, (2) to create online media learning in using kahoot and comic strip application, (3) to product yield was worth to examined by validator and students respondence due to development testing to increase integrated science comprehension for students grade viii with score amount 3,76 and 3.24 and, (4) the last result of the product were effective to increase cognitive value for students of SMP grade VIII. As a result of learning, which prove by pretest average score amount 55,3, then up to 84,2 after post test. the comparation $t$ count for $t$ table amont 2,283 $>1,99897$ and independent test $t$ amount $0,026<0,05$. These were prove thhat media learning capable to increase cognitive value for science subject of students grade VIII SMPK st, fransiskus Asisi samarinda. Therefore the evaluation media learning which developed was deserve to used by students of SMP grade VIII In Samarinda.
\end{abstract}

Keywords: Media Learning, Kahoot Application, Comic Strip Application, Cognitive Learning Score.

\section{PENDAHULUAN}

Perkembangan pendidikan di dunia tidak lepas dari adanya perkembangan dari revolusi industri, karena secara tidak langsung perubahan tatanan ekonomi turut merubah tatanan pendidikan di suatu negara. Oleh karena itu guru abad 21 harus bisa menciptakan proses pembelajaran yang menarik dan menghibur agar tidak kalah dengan zaman yang semakin canggih. Hasil angket pendahuluan yang disebarkan kepada 64 peserta didik kelas VIII di SMPK Fransiskus Asisi Samarinda menunjukkan bahwa peserta didik tertarik terhadap pembelajaran IPA konsentrasi biologi. Peserta didik senang membaca buku cetak biologi, dan senang bila belajar biologi dengan gambar, namun terdapat kekurangan seperti tampilan yang kurang menarik, banyak mengandung tulisan, tebal, serta kurang praktis dan efisien. Hasil wawancara guru yang dilakukan saat observasi menunjukkan bahwa penggunaan media pembelajaran yang digunakan sudah cukup bervariasi. Namun para guru mengaku bahwa mereka belum pernah membuat ataupun menggunakan media komik dalam pembelajaran biologi, sehingga penelitian ini bisa jadi keterbaharuan dalam proses pembelajaran baik untuk guru maupun peserta didik. Dari hasil angket peserta didik dalam kesehariannya belajar IPA biologi, penggunaan powerpoint lebih monoton dan membuat peserta didik merasa bosan dan mengantuk. Hal ini menunjukkan bahwa teknologi belum banyak dimanfaatkan sebagai media pembelajaran. Akibatnya, sebanyak $67 \%$ peserta didik masih menganggap mata pelajaran ini sulit.

Salah satu materi pada pelajaran biologi kelas VIII SMA adalah materi sistem ekskresi. Materi ini mencakup sistem organ ekskresi, pengeluaran metabolisme urin hingga gangguan dan penanganan terhadap gangguan/penyakit dalam sistem ekskresi. Berdasarkan cakupan materi tersebut, banyak sekali konsep yang harus dihafal dan dipahami, sedangkan peserta didik masih merasa kesulitan untuk mengingat banyak konsep jika hanya diterangkan lewat 
media powerpoint dan torso saja. Upaya yang dilakukan agar dapat memudahkan peserta didik dalam proses belajar dan mengurangi kesalahan konsep dalam pemahaman materi sistem organ ekskresi adalah dengan memberikan sebuah media pembelajaran alternatif sekaligus menciptakan proses belajar yang menyenangkan.

Perkembangan zaman di era teknologi abad 21 ini telah melahirkan banyak media visual yang dapat dikembangkan adalah komik. Penggunaan media komik diakui dapat membantu proses pembelajaran, terutama membantu meningkatkan minat, motivasi, dan hasil belajar peserta didik. Proses pengembangan media pembelajaran komik digital ini mempertimbangkan sarana dan prasarana di sekolah. Penelitian ini dilaksanakan di SMPK St. Fransiskus Asisi Samarinda karena berdasarkan hasil observasi telah didukung dengan teknologi informasi berupa komputer, LCD projector, tersedia jaringan internet (wifi) di sekolah, dan peserta didik sudah terbiasa menggunakan perangkat elektronik serta internet baik di sekolah maupun di luar sekolah. Hasil angket pendahuluan menunjukkan bahwa peserta didik sudah memiliki perangkat elektronik berupa smarthphone, tablet, laptop, dan komputer. Sebanyak $91 \%$ peserta didik sudah pernah membaca komik dari berbagai media seperti koran, majalah, buku komik, dan internet, kemudian $100 \%$ peserta didik mendukung dilakukannya pengembangan media pembelajaran dalam bentuk komik digital disertai quiz pada konsep sistem ekskresi. Berdasarkan latar belakang tersebut, penelitian ini mengangkat judul: "Pengembangan Media Pembelajaran (Online) Berbantuan Aplikasi Kahoot dan Komik Strip Dalam Upaya Meningkatkan Nilai Kognitif Siswa Kelas VIII SMPK St. Fransiskus Asisi Samarinda"

\section{TINJAUAN PUSTAKA \\ Komik Strip}

Komik strip adalah komik yang hanya terdiri dari beberapa panel gambar saja, namun dilihat dari segi isi ia telah mengungkapkan sebuah gagasan yang utuh, tentu saja karena gambarnya hanya sedikit gagasan yang disampaikan juga tidak banyak. Komik yang dikembangkan tidak hanya berisi materi saja melainkan memuat pendidikan karakter seperti kepedulian terhadap lingkungan, kejujuran, tanggung jawab, gemar membaca, dan rasa ingin tahu. Mengingat bahwa belakangan ini sikap siswa yang semakin memprihatinkan, dikarenakan kurangnya pendidikan karakter yang ditanamkan. Jadi dengan adanya media komik, tidak hanya membantu siswa dalam memahami materi, tetapi juga sekaligus membantu guru dalam mendidik siswa untuk bersikap.

\section{Aplikasi Pembuatan Quiz Sebagai Media Belajar}

Pembuatan quiz dalam penelitian ini menggunakan program web bernama Kahoot. Kahoot adalah platform pembelajaran berbasis game dan terbagi ke dalam enam jenis yaitu quiz, true or false, puzzle, slide, poll, dan question bank Penelitian ini menggunakan Kahoot jenis quiz.

Untuk membuat permainan Kahoot, kita perlu login ke situs Kahoot (https://getkahoot.com) lalu dapat langsung membuat pertanyaan dengan menggunakan pilihan yang tersedia. Setelah selesai dan disimpan, kita dapat langsung memulai quiz dengan memilih icon play. Saat memulai permainan, kita akan memperoleh kode unik dimana nantinya kode itu sebagai kunci agar peserta didik dapat masuk ke dalam quiz yang dibuat. Peserta didik sebagai pemain dapat menjawab pertanyaan melalui perangkat mereka sendiri dengan memasukkan kode yang muncul di layar dan mengetik nama mereka, sementara pertanyaan dan pilihan jawaban ditampilkan di layar. Setelah quiz Kahoot dimulai, para peserta didik akan memperoleh poin, besar kecilnya poin yang diperoleh berdasarkan siapa yang cepat dan benar dalam menjawab pertanyaan. Kegiatan ini membuat suasana yang 
membangkitkan semangat para peserta didik sebagai pemain dalam proses pembelajaran.

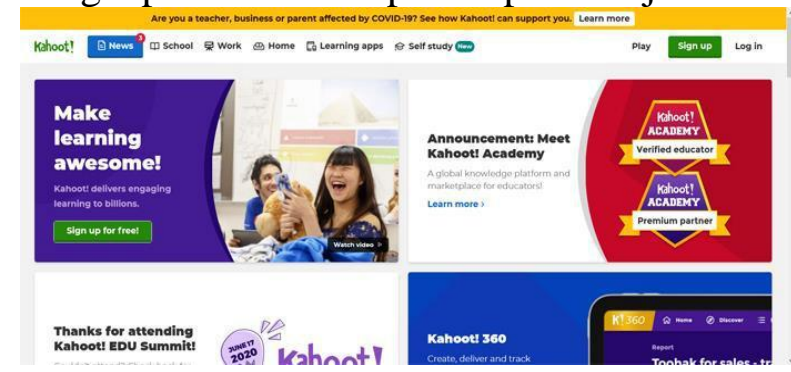

Halaman Utama Kahoot

\section{METODOLOGI PENELITIAN}

Jenis penelitian yang digunakan dalam penelitian ini adalah Research and Development (R \& D) Penelitian dan pengembangan dilaksanakan melalui beberapa langkah. Desain penelitian ini menggunakan model pengembangan desain pendidikan yang dikembangkan oleh Jan Van Den Akker. Penelitian ini mulai dilakukan pada Agustus 2019 s/d Agustus 2020 selama tahun pembelajaran (2019/2020). Adapun tempat yang dijadikan lokasi penelitian menggunakan dua kelas pada SMPK St. Fransiskus Asisi Samarinda sebagai perwakilan sekolah SMP yang ada di Kota Samarinda.

\section{Variabel dan Definisi Operasional}

Variabel penelitian adalah segala sesuatu yang berbentuk apa saja yang ditetapkan oleh peneliti untuk dipelajari sehingga diperoleh informasi tentang hal tersebut, kemudian ditarik kesimpulannya (Sugiyono, 2014). Variabel dalam penelitian ini terdiri dari dua macam, yaitu:

1. Variabel bebas (independen), berupa pemanfaatan pengembangan Media Pembelajaran (Online) Berbantuan Aplikasi Kahoot dan Komik Strip.

2. Variabel terikat (dependen), berupa nilai belajar kognitif siswa. Indikator yang dipakai untuk mengukur variabel dependen ini adalah nilai pengetahuan yang diambil dari nilai tugas dan nilai ulangan harian yang disesuaikan dengan hasil analisis terhadap kurikulum.
Populasi penelitian adalah Seluruh siswa kelas VIII di SMP St. Fransiskus Asisi Samarinda, dan Sampelnya adalah siswa kelas VIII.1 dan VIII.2 sebagai kelas uji meluas sedangkan kelas VIII-3 sebagai kelas uji coba produk/terbatas. Sampel kelompok eksperimen dan kontrol pada setiap uji coba dilakukan dengan pembagian proporsional yaitu 50\% kelompok kontrol dan 50\% kelompok eksperimen (memberi media). Sedangkan perlakuan didalam kelas sama.

\section{Teknik Analisis Data}

Teknik analisis data yang akan dilakukan pada penelitian ini adalah teknik analisis deskriptif dan parametris. Teknik analisis deskriptif dilakukan dengan menggunakan statistik deskriptif. Untuk menentukan beberapa kategori kelayakan dari bahan ajar ini, maka dipakai skala pengukuran skala Likert. Hasil angket dianalisis dengan kriteria sebagai berikut:

$$
t=\frac{\bar{X}_{1}-\bar{X}_{2}}{\sqrt{\frac{s_{1}^{2}}{n_{1}}+\frac{s_{2}^{2}}{n_{2}}-2 r\left[\frac{s_{1}}{\sqrt{n_{1}}}\right]\left[\frac{s_{2}}{\sqrt{n_{2}}}\right]}}
$$

Skor yang diperoleh dari angket kemudian dikonversikan untuk diketahui persentase kelayakan, persentase ditentukan dengan rumus sebagai berikut menurut Arikunto (2012: 244):

Kelayakan $=\frac{\text { skor yang diperoleh }}{\text { skor maksimal yang dapat diperoleh }} \times$

Kemudian setelah diketahui hasil perhitungan,diidentifikasikan ke dalam kategori sesuai dengan tabel.

\begin{tabular}{|c|c|c|}
\hline $\begin{array}{c}\text { Skor } \\
\text { Penilaian }\end{array}$ & Rentang Skor & Kategori \\
\hline 4 & $75 \%-100 \%$ & $\begin{array}{c}\text { Sangat } \\
\text { Layak }\end{array}$ \\
\hline 3 & $56 \%-75 \%$ & Layak \\
\hline
\end{tabular}


Jurnal Ilmu Sosial dan Pendidikan

http://ejournal.mandalanursa.org/index.php/JISIP/index

Terakreditasi Peringkat 5 (No. SK: 85/M/KPT/2020)

\begin{tabular}{|c|c|c|}
\hline 2 & $40 \%-55 \%$ & $\begin{array}{c}\text { Cukup } \\
\text { Layak }\end{array}$ \\
\hline 1 & $0 \%-39 \%$ & Kurang \\
\hline
\end{tabular}

Pedoman konversi di atas digunakan

untuk menentukan kelayakan produk pengembangan Media Pembelajaran. Penilaian tersebut dapat membantu pengembangan media menjadi lebih baik dari aspek materi maupun aspek media pembelajaran. Sedangkan statistik parametris digunakan untuk menganalisa hipotesis penelitian ini pada fase disseminate, yaitu dengan menggunakan independent t-test menggunakan SPSS 20. Adapun rumus uji statistik independent $t$-test related sebagai berikut:

Dimana:

$\overline{X 1}$ : Rata - rata sampel 1 (tidak menggunakan media evaluasi pembelajaran)

$\overline{X 2}$ : Rata - rata sampel 2 (menggunakan media evaluasi pembelajaran)

S1 : Simpangan baku sampel 1

S2 : Simpangan baku sampel 2

$s 12$ : Varian sampel 1

$s 22$ : Varian sampel 2

Korelasi antara data dua kelompok Jika :

$$
\begin{gathered}
\text { Ho }: \mu 1<\mu 2 \\
\text { sedangkan } \\
\text { Ha }: \mu 1>\mu 2
\end{gathered}
$$

Bila $t$ hitung jatuh pada daerah penerimaan $\mathrm{Ha}$, maka Ha yang menyatakan bahwa menggunakan media evaluasi pembelajaran (Online) berbantuan aplikasi kahoot dan komik strip lebih baik dari bahan ajar sebelumnya. Dengan demikian, dapat disimpulkan bahwa terdapat perbedaan yang signifikan antara menggunakan media evaluasi pembelajaran (Online) berbantuan aplikasi kahoot dan komik strip dan yang tidak.

\section{HASIL DAN PEMBAHASAN Hasil Penelitian}

Pengembangan media pembelajaran (Online) berbantuan aplikasi Kahoot dan Komik
Vol. 5. No. 1 Januari 2021

p-ISSN: 2598-9944 e- ISSN: 2656-6753

Strip pada pokok bahasan sistem ekskresi yang disusun dan dikembangkan berdasarkan model pengembangan desain pendidikan yang terdiri dari empat tahapan yaitu penelitian pendahuluan, tahap prototipe, evaluasi sumatif, refleksi sistematis dam dokumentasi. Adapun hasil yang diperoleh pada tiap-tiap tahapan pengembangan perangkat pembelajaran berbasis keterampilan informasi yang dimaksud diuraikan sebagai berikut.

\section{Tahap Penelitian Pendahuluan}

Pada tahap ini diuraikan hasil pengkajian yang dilakukan tentang media. Proses ini meliputi lima langkah, yaitu:

a. Hasil Analisis Awal-Akhir

Analisis awal-akhir bertujuan untuk mengidentifikasi masalah esensial yang dihadapi oleh guru dalam meningkatkan prestasi belajar peserta didik.

Berdasarkan kenyataan yang ada di lapangan menunjukkan masih banyak peserta didik yang sulit memahami pelajaran IPA yang salah satunya adalah materi sistem ekskresi karena sulitnya memahami istilah-istilah dan namanama pada bagian pada organ ekskresi. Selain itu masih banyak guru yang melakukan pembelajaran di sekolah menggunakan media belajar yang kurang melibatkan peserta didik dalam belajar. Hal ini mengakibatkan peserta didik tidak terampil dalam mengkonstruksi pengetahuan karena peserta didik hanya sekedar mendengarkan dan mencatat materi yang disampaikan oleh guru sehingga mengakibatkan rasa bosan dankurang bergairah dalam proses pembelajaran.

Hal ini disebabkan karena perangkat yang digunakan masih sangat sederhana hanya berdasarkan langkah-langkah yang ada dari buku paket dengan berbagai penerbit. Atau terkadang dibuatkanlembar kerja tapi bentuknya kurang

b. Hasil Analisis Peserta Didik

Analisis peserta didik dilakukan untuk mengetahui karakteristik peserta didik yang sesuai dengan rancangan dan pengembangan bahan pembelajaran. Dari hasil observasi 
diperoleh data tentang karakteristik peserta didik sebagai berikut:

1) Usia rata-rata peserta didik yang menjadi subjek penelitian adalah 14-15 tahun, dimana pada usia ini peserta didik mulai mengelola dan menganalisis informasi serta mulai mengembangkan kemampuan bernalar dengan cara yang konkret menuju abstrak.

2) Kemampuan akademik peserta didik kelas VIII SMPK St. Fransiskus Asisi tahun pelajaran 2016-2017 bersifat heterogen, yaitu berkemampuan tinggi, sedang, rendah.

3) Peserta didik kelas VIII SMPK St. Fransiskus Asisi memiliki latar belakang yang berbeda, baik dari suku, maupun latar belakang pendidikan orang tua, penghasilan orang tua maupun status sosial di masyarakat.

4) Dilihat dari latar belakang pengetahuan, peserta didik belum spesifik memperoleh pembelajaran tentang materi ekskresi, selain itu dalam kehidupan sehari-hari analysis informasi bersifat abstrak sehingga perlu dibantu media pendukung dalam menjelaskan bahasan ini.

c. Hasil Analisis Materi

Kegiatan yang dilakukan pada langkah ini adalah mengidentifikasi, merinci,dan menyusun secara sistematis materi-materi utama yang dipelajari peserta didik. Materi pelajaran dalam penelitian ini adalah materi sistem ekskresi manusia (Ginjal). Garis-garis besar materi adalah (1) Organ Penyusun: Ginjal, Kulit, Paru-paru dan Hati, (2) Pembentukan Urin Pada Ginjal, (3) Penyakit dan Gangguan, (4) Upaya memelihara organ ekskresi.

c. Hasil Analisis Tugas

Berdasarkan analisis materi sistem ekskresi pada manusia khsusunya pada Ginjal, diperoleh tugas-tugas atau indikatorpencapaian pembelajaran sebagai berikut: (1) Menganalisis bagian-bagian penyusun ginjal, Mengidentifikasi bagian dan fungsi ginjal, (3) Menganalisis proses pembentukan urin, (4) Menganalisis kelainan dan gangguan pada sistem ekskresi manusia pada ginjal dan (5) Upaya memelihara kesehatan organ ginjal dari kelainan dan gangguan pada sistem ekskresi ginjal.

d. Hasil Analisis Spesifikasi Tujuan Pembelajaran

Hasil analisis spesifikasi tujuan pembelajaran untuk: (1) Menganalisis bagian-bagian penyusun ginjal, (2) Mengidentifikasi bagian dan fungsi ginjal, (3) Menganalisis proses pembentukan urin, (4) Menganalisis kelainan dan gangguan pada sistem ekskresi manusia pada ginjal dan (5) Upaya memelihara kesehatan organ ginjal dari kelainan dan gangguan pada sistem ekskresi ginjal.

\section{Tahap prototipe}

Tahap prototipe adalah tahap yang dilakukan setelah tahap penelitian pendahuluan dengan membuat perancangan desain produk, evaluasi formatif dan revisi.

a. Perancangan Materi Ajar

Materi ajar yang dipilih adalah sistem ekskresi berdasarkan saran dari dosen pembimbing mengingat program web yang digunakan adalah Komik Strip dan Kahoot. Tahap selanjutnya setelah pemilihan materi adalah menganalisis Kompetensi Inti (KI) dan Kompetensi Dasar (KD) berdasarkan Permendikbud No. 24 tahun 2016 tentang Kompetensi Inti (KI) dan Kompetensi Dasar (KD) IPA SMP kelas VIII pada kurikulum 2013. Hal tersebut dilakukan untuk membuat tujuan dan indikator pembelajaran agar dapat membuat naskah komik dan menyusun soal evaluasi yang akan dimasukkan ke dalam quiz.

\section{Tahap Evaluasi Sumatif}

Tahap evaluasi formatif merupakan tahap mengevaluasi produk prototip yang telah dibuat. Tahap evaluasi formatif terdiri dari validasi ahli dan validasi media. Ahli media merupakan dosen dari Fakultas KIP di Universitas Mulawarman, Bpk. Abdul Hakim dan Ahli Bahasa oleh Bpk. Yusak Hudiyono. Ahli memberikan penilaian layak dengan rata-rata skor sebsar 3,0. Hal tersebut mengandung arti 
Jurnal Ilmu Sosial dan Pendidikan

http://ejournal.mandalanursa.org/index.php/JISIP/index

Terakreditasi Peringkat 5 (No. SK: 85/M/KPT/2020)

bahwa validasi media dalam produk bahan ajar interaktif layak untuk dilanjutkan. Berdasarkan penilaian ahli media pada aspek isi diperoleh rerata skor secara keseluruhan sebesar 3,43 yang secara kualitatif dikategorikan sangat layak $(\mathrm{X} \geq$ $3,0)$.

\section{Tahap Refleksi Sistematis dan Dokumentasi}

Tahap refleksi sistematik dan dokumentasi adalah tahap akhir dari prosedur pengembangan ini. Tahap ini merupakan tahap deskripsi penelitian pengembangan media komik disertai quiz yang telah dilakukan dalam bentuk laporan. Hasil laporan penelitian pengembangan berdasarkan tahapan, respon, dan hasil pengembangan.

Penelitian pada kelompok ini dilakukan pada siswa kelas VIII-1 SMPK St. Fransiskus Asisi yang berjumlah 32 siswa dan VIII-2 berjumlah 32 siswa. Peneliti membagi kelas menjadi 2 kelompok yaitu kelompok A yang diberi media interaktif untuk digunakan dirumah dan disekolah. Sedangkan kelompok B tidak diberi media belajar sejenis melainkan panduan biasa/umumnya. Sampel yang diambil dalam uji coba terbatas ini dilakukan pada keseluruhan siswa yang berjumlah 30 siswa.

Sebelum pelajaran berlangsung siswa melaksanakan kegiatan uji pre tes untuk mengetahui kemampuan awal belajar. Kemudian diberi materi belajar sesuai bahan ajar yaitu sistem ekskresi manusia selama 5 kali pertemuan. Di akhir pertemuan, siswa diberi post tes menggunakan aplikasi quiz untuk mengetahui kemampuan akhir/ daya serap siswa. Adapun data pre test dan post tes yang dihasilkan dapat terlihat pada tabel berikut:

Daftar Nilai IPA Siswa Kelas VIII-3 (Uji Terbatas)

\begin{tabular}{|c|c|c|c|c|c|}
\hline \multicolumn{3}{|c|}{ A } & \multicolumn{3}{c|}{ B } \\
\hline \multirow{2}{*}{ No } & \multicolumn{2}{|c|}{ Nilai } & \multirow{2}{*}{ No } & \multicolumn{2}{c|}{ Nilai } \\
\cline { 2 - 3 } \cline { 5 - 6 } & $\begin{array}{c}\text { Pre- } \\
\text { Test }\end{array}$ & $\begin{array}{c}\text { Post- } \\
\text { Test }\end{array}$ & & $\begin{array}{c}\text { Pre- } \\
\text { Test }\end{array}$ & $\begin{array}{c}\text { Post- } \\
\text { Test }\end{array}$ \\
\hline A1 & 42 & 88 & B1 & 33 & 75 \\
\hline A2 & 20 & 69 & B2 & 30 & 74 \\
\hline A3 & 34 & 74 & B3 & 30 & 72 \\
\hline
\end{tabular}

Vol. 5. No. 1 Januari 2021

p-ISSN: 2598-9944 e-ISSN: 2656-6753

\begin{tabular}{|c|c|c|c|c|c|}
\hline A4 & 26 & 72 & B4 & 42 & 82 \\
\hline A5 & 43 & 90 & B5 & 39 & 76 \\
\hline A6 & 28 & 85 & B6 & 32 & 70 \\
\hline A7 & 32 & 86 & B7 & 29 & 71 \\
\hline A8 & 42 & 85 & B8 & 30 & 75 \\
\hline A9 & 38 & 84 & B9 & 37 & 83 \\
\hline A10 & 46 & 91 & B10 & 49 & 86 \\
\hline A11 & 42 & 89 & B11 & 48 & 88 \\
\hline A12 & 26 & 76 & B12 & 30 & 71 \\
\hline A13 & 43 & 87 & B13 & 38 & 74 \\
\hline A14 & 26 & 73 & B14 & 40 & 82 \\
\hline A15 & 30 & 77 & B15 & 26 & 70 \\
\hline & 35,3 & 83,3 & & 35,9 & 77 \\
\hline
\end{tabular}

Berdasarkan pada data ini, dapat terlihat perbedaan1 rata-rata belajar kelompok A (Eksperimen) dan kelompok B (Kontrol) baik pre tes maupun post tes.

Dari data pre tes, kelompok eksperimen dan kontrol tidak jauh berbeda sehingga bisa diasumsikan siswa dari kedua kelompok memiliki kemampuan homogen dan sebanding, yaitu 35,3 : 35,9. Namun setelah diberi perbedaan media ajar dan kesamaan pengajaran didepan kelas, pengaruhnya signifikan yaitu $83,3: 77$.

Sebagai pembanding, peneliti juga menggunakan uji $\mathrm{t}$ (independen t-test) menggunakan IBM Statistik SPSS 22. Adapun hasil dan deskripsi analisis uji t sebagai berikut:

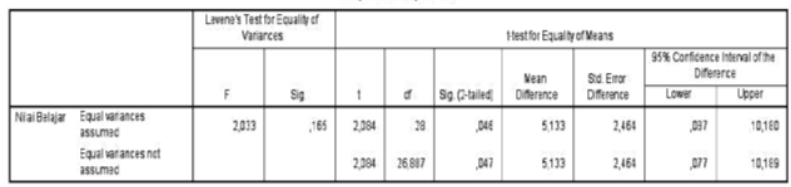

Untuk mengetahui ada atau tidaknya perbedaan rata-rata nilai belajar antara kelompok A (eksperimen) dan kelompok B (kontrol), terlebih dahulu menentukan hipotesis penelitiannya.

a. $\mathrm{H}_{0}$ diartikan sebagai tidak terdapat perbedaan rata-rata nilai belajar kelompok $\mathrm{A}$ dan B

b. $\mathrm{H}_{\mathrm{A}}$ diartikan sebagai memiliki perbedaan rata-rata nilai belajar kelompok $\mathrm{A}$ dan $\mathrm{B}$

Berdasarkan tabel uji $\mathrm{t}$ diatas nilai signifikannya adalah sebesar 0,165>0,05. Maka 
Jurnal Ilmu Sosial dan Pendidikan

http://ejournal.mandalanursa.org/index.php/JISIP/index

Terakreditasi Peringkat 5 (No. SK: 85/M/KPT/2020)

dapat diartikan bahwa varians data antara A dan B adalah homogen atau sama. Sedangkan berdasar tabel output independent $t$ test for equality pada bagian equal varian assumed diketahui nilai sig. (2-tailed) sebesar 0,046< 0,05 , maka sebagaimana dasar dalam pengambilan keputusan uji independen t-test dapat disimpulkan bahwa $\mathrm{H}_{0}$ ditolak dan $\mathrm{H}_{\mathrm{a}}$ diterima. Dengan demikian, dapat disimpulkan bahwa terdapat perbedaan yang signifikan (nyata) antara hasil belajar pada kelompok A dan kelompok B. Selisih rata-rata antara kelompok belajar A dan kelompok B sebesar $+5,133$ dan nilai rata dikelompok A lebih tinggi dibanding $\mathrm{B}$ dengan interval 0,087 s.d 10,180.

\section{Pembahasan}

Produk akhir yang dihasilkan berupa media evaluasi pembelajaran (Online) berbantuan aplikasi kahoot dan komik strip yang dapat dibaca pada layar komputer/laptop dan digunakan juga secara online. Produk media interaktif evaluasi ini dikembangkan didasar kan pada analisis kebutuhan di SMPK Fransiskus Asisi Samarinda. Analisis kebutuhan diperoleh dari hasil observasi awal, dan wawancara dengan guru dan siswa.

Berdasarkan hasil UN yang dilakukan secara berturut-turut tiga tahun terakhir juga menjadi alasan dilakukannya penelitian pengembangan ini. Permasalahan utama terlihat dalam materi yang diuji yaitu struktur dan fungsi makhluk hidup dengan skor 53,30 lebih tinggi 4,18 poin dibanding hasil UN 2018/2019 tingkat kota. Indikator terendah pada penjelasan ciri pembuluh darah dengan skor 22,73 dan penjelasan keterkaitan sistem organ pada manusia 27,27.

Pada tahap refleksi sistematis dan dokumentasi, dapat terlihat perbedaan rata-rata belajar kelompok A (Eksperimen) dan kelompok B (Kontrol) baik pre tes maupun post tes. Dari data pre tes, kelompok eksperimen dan kontrol tidak jauh berbeda sehingga bisa diasumsikan siswa dari kedua kelompok memiliki kemampuan homogen dan sebanding, yaitu 35,3
Vol. 5. No. 1 Januari 2021

p-ISSN: 2598-9944 e- ISSN: 2656-6753

: 35,9. Namun setelah diberi perbedaan media ajar dan kesamaan pengajaran didepan kelas, pengaruhnya signifikan yaitu 83,3:77.

Berdasarkan tabel uji $t$ diatas nilai signifikannya adalah sebesar $0,165>0,05$. Maka dapat diartikan bahwa varians data antara A dan B adalah homogen atau sama. Sedangkan berdasar tabel output independent $\mathrm{t}$ test for equality pada bagian equal varian assumed diketahui nilai sig. (2-tailed) sebesar 0,046< 0,05 , maka sebagaimana dasar dalam pengambilan keputusan uji independen t-test dapat disimpulkan bahwa $\mathrm{H}_{0}$ ditolak dan $\mathrm{H}_{\mathrm{a}}$ diterima. Dengan demikian, dapat disimpulkan bahwa terdapat perbedaan yang signifikan (nyata) antara hasil belajar pada kelompok A dan kelompok B. Selisih rata-rata antara kelompok belajar A dan kelompok B sebesar $+5,133$ dan nilai rata dikelompok A lebih tinggi dibanding $\mathrm{B}$ dengan interval 0,087 s.d 10,180

Hasil wawancara dengan siswa diperoleh bahwa siswa membutuhkan media belajar dan evaluasi yang membutuhkan gambar yang menarik, dengan kombinasi jalan cerita yang asik. Oleh karena itu, produk media interaktif diharapkan dapat menjadi salah satu alternatif yang dapat memudahkan siswa dalam memahami konsep yang disajikan. Ruang lingkup materi yang dikembangkan adalah struktur dan fungsi makhluk hidup yang terdiri dari materi pada sistem ekskresi. Untuk memudahkan visualisasi materi, media interaktif belajar hingga evaluasi dikemas dalam bentuk digital. Tujuannya adalah siswa dapat mengkontrol sendiri baik navigasi maupun materinya. Siswa dapat dengan leluasa berpindah antar halaman, menonton, menjeda, dan memutar ulang konten animasi maupun video (Lee,dkk: 2016)

Produk bahan ajar interaktif yang dikembangkan diuji alpha oleh ahli materi dan media yang menguasai bidangnya. Berdasarkan hasil penilaian ahli materi diperoleh rata-rata skor sebesar 3,42 dengan kategori layak dan kesimpulan dapat dilanjutkan dengan revisi. Sehingga materi yang disajikan dalam produk 
bahan ajar interaktif dinyatakan layak digunakan dengan revisi sesuai saran yang diberikan. Selanjutnya, hasil validasi media diperoleh ratarata skor sebesar 3,02 dengan kategori layak, sehingga produk media evakuasi pembelajaran dinyatakan layak digunakan sesuai dengan revisi yang disarankan ahli materi dan media.

Setelah melakukan uji coba dan kajian terhadap produk bahan ajar interaktif, terdapat beberapa aspek kelemahan dari produk tersebut diantaranya sebagai berikut:

1. Produk merupakan media yang hanya dapat dioperasikan secara online sehingga operasionalnya mengikuti kebutuhan jaringan dan paket data.

2. Jumlah item tulisan soal pada kuis sangat terbatasi, sehingga soal yang ditampilkan adalah yang singkat perpoin dan selebihnya dikembangkan melalui tampilan gambar komik.

3. Bahan ajar interaktif sudah didukung dengan pengunaan perangkat smartphone, maupun komputer ataupun laptop. Namun tetap perlu dilengkapi aplikasi tambahan demi perbaikan konten

4. Media interaktif belum didukung dengan adanya lembar kerja, hanya tersedia latihan soal berbentuk pilihan ganda dan esai.

\section{KESIMPULAN}

Berdasarkan penelitian yang telah dilakukan dapat diambil beberapa kesimpulan sebagai berikut:

1. Kevalidan Media Pembelajaran (Online) berbantuan aplikasi kahoot dan komik strip. Berdasarkan hasil hasil observasi, dan wawancara Media Pembelajaran (Online) berbantuan aplikasi kahoot dan komik strip merupakan strategi belajar yang valid dan dapat digunakan dalam proses pembelajaran di kelas. Melalui cara prosedur pengembangan dan proses validasi dari sebelumnya, yaitu validasi dari ahli perangkat pembelajaran dan ahli bahasa, sehingga Media Pembelajaran (Online) berbantuan aplikasi kahoot dan komik strip menjadi media yang baik untuk digunakan dalam proses belajar dan pembelajaran.

2. Keefektifan Media Pembelajaran (Online) berbantuan aplikasi kahoot dan komik strip.

Berdasarkan data hasil belajar dengan menggunakan Media Pembelajaran (Online) berbantuan aplikasi kahoot dan komik stripyang telah diimplentasikan oleh guru, terbukti bahwa dapat meningkatkan hasil belajar kognitif siswa. Hal tersebut diperkuat dengan hasil uji efektivitas Media Pembelajaran (Online) berbantuan aplikasi kahoot dan komik strip. Dari hasil perhitungan statistik menunjukkan terdapat perbedaan yang signifikan nilai rata-rata hasil belajar biologi aspek kognitif peserta didik pretest (sebelum tindakan) dan posttest (setelah tindakan).

\section{SARAN}

Berdasarkan kesimpulan dan implikasi di atas, maka peneliti mengajukan saran sebagai berikut:

1. Kepada Kepala Sekolah

Selalu merespon terhadap perkembangan teori mengenai strategi belajar dan menghimbau guru-guru untuk menerapkan strategi belajar yang dapat menjadikan siswa lebih aktif.

2. Kepada Guru

a. Dalam pembelajaran di kelas, guru lebih kreatif menggunakan media pembelajaran (Online).

b. Dalam pembelajaran guru memberikan kesempatan untuk melatih peserta didik dalam belajar menemukan jawabannya sendiri, guru menggunakan strategi dan media belajar yang menjadikan peserta didik lebih aktif.

c. Kepada Peserta Didik

Hendaknya peserta didik menjadi lebih giat belajar dan berfikir bahwa pembelajaran itu tidak hanya dilakukan di kelas namun mereka bisa belajar di rumah dan dimanapun dengan Media 
Pembelajaran (Online) berbantuan aplikasi kahoot dan komik strip.

\section{DAFTAR PUSTAKA}

Alessi, S. M. \& Trollip, R. S. (2001). Multimedia for learning: Methods and Development ( ${ }^{\text {rd }}$ ed.). Boston: Allyn and Bacon

Amri, Sofwan dan Ahmadi Iif Khoirul. 2010.

Konstruksi Pengembangan
Pembelajaran Pengaruhnya
Terhadap Mekanisme dan Praktik
Kurikulum. Jakarta: Prestasi Pustaka
Publisher

Bardi \& Jailani. 2015. Pengembangan Multimedia Berbasis Komputer Untuk Pembelajaran Matematika Bagi Siswa SMA. Jurnal Inovasi Teknologi Pendidikan, 2(1), 49-63.

Beny H. Firmansyah, Anselmus J.E.T, Saida U. 2016. Universal Design For Learning Sebagai Sarana Untuk Memfasilitasi Perbedaan Gaya Belajar Peserta Didik dalam Belajar. Prosiding Seminar Nasional Teknologi Pembelajaran dan Psikologi Pendidikan. Malang: PPs UM. Hal: $59-66$

Brown, H.D. 2000. Principles of Language Teaching and Learning (4th Edition). White Plains, Ny: Longman

BSNP. 2006. Instrumen Penilaian Buku Teks Pelajaran Pendidikan Dasar Menengah. Jakarta: Depdiknas

Center for Applied Special Technology (CAST). 2013. Universal Design for Learning Guidelines Version 1.0. Wakefeld, MA: Author

Chatib, Munif. 2012. Sekolahnya Manusia. Bandung: Kaifa

Daryanto. 2013. Menyusun Modul, Bahan Ajar Untuk Persiapan Guru Dalam Mengajar. Yogyakarta: Penerbit Gava Media

DePorter, B., \& Reardon, M., \& Singer-Nourie, S. 1999. Quantum Teaching:
Mempraktikkan Quantum Learning di Ruang-Ruang Kelas. Terjemahan oleh Ari Nilandri. 2000. Bandung: Kaifa

Direktorat Pembinaan SMA. 2010. Juknis pengembangan bahan ajar SMA. Diambil pada tanggal 12 Juni 2019, dari

https://suaidinmath.files.wordpress.c om/2011/01/22-juknis-

pengembanganbahan-ajar-_isi-

revisi_0104.pdfEdyburn, D. 2009. RTI and UDL Interventions. Journal of Special Education Technology, 24(2), 46-47.

Fakhriyah, F., S. Masfuah, \& M. Roysa. (2018). Readability of Conceptual Science Material Teaching based on Science Literacy Using Modified Cloze Test Technique to Develop Computational Thinking Skills. Proceeding Advances in Social Science, Education and Humaniities Research. Volume 262.

Hardianto, Deny. 2005. Media Pendidikan sebagai Sarana Pembelajaran yang Efektif. Majalah Ilmiah Pembelajaran 1, Vol. 1. Hlm 95-104

Hitchcock, Chuk., Meyer, Anne., Rose, David., \& Jackson, Richard. 2002. Providing New Access to the General Curriculum: Universal Design for Learning. TEACHING Exceptional Children, 35, 8-17

Israel, Maya., Ribuffo, Cecelia., \& Smith, Sean. 2014. Universal Design for Learning: Recommendations for Teacher Preparation and Proffesional Development. The CEEDAR Center. Gainsville: University of Florida

Iqbal, M.J. 2006. Modular Approach in Teaching. Allama Iqbal Open University Islamabad: Departement of Distance \& Non Formal Education. 
Jimenez, T.C., Graf, V.L., \& Rose, E. 2007. Gaining Access To General Education: The Promise of Universal Design For Learning. Issues in Teacher Education, 16(2), 41-54. Retrieved from http://www.eric.ed.gov/PDFS/EJ796 250.pdf

Lestari, I. 2013. Pengembangan Bahan Ajar Berbasis Kompetensi. Jakarta: Akademia Permata

Majid, A. (2009). Perencanaan Pembelajaran Mengembangkan Kompetensi Guru. Bandung:

Mudlofir, A. 2012. Aplikasi Pengembangan KTSP Dan Bahan Ajar Dalam Pendidikan Agama Islam. Jakarta: PT RajaGrafindo Persada.

Mulyatiningsih, E. 2012. Metode Penelitian Terapan Bidang Pendidikan. Bandung: Penerbit Alfabeta.

Nasution, S. 2003. Berbagai Pendekatan dalam Proses Belajar Mengajar. Jakarta: Bumi Aksara

Permendikbud No. 24 Tahun 2016 tentang Kompetensi Inti dan Kompetensi Dasar Pelajaran Pada Kurikulum 2013 Pada Pendidikan Dasar dan Pendidikan Menengah.

Riyana, C. (2007). Pedoman pengembangan modul multimedia interaktif. Bandung: Program P3AI UPI.

Rose, D. H., \& Meyer, A. 2002. Teaching Every Student In The Digital Age: Universal Design For Learning. Alexandria, VA: Association for Supervision and Curriculum Development. Retrieved from http://www.cast.org/teachingeveryst udent/ideas/tes

Rumansyah, M. 2016. Perbedaan Pengaruh Pembelajaran Dengan Menggunakan Modul Interaktif dan Modul Konvensional Terhadap Pemahaman Konsep IPA. Jurnal
Pendidikan Matematika dan Sains, 4 (1), 54-62.

Sadjati, Ida Malati. 2012. Hakikat Bahan Ajar (Modul Pengembangan Bahan Ajar). Jakarta: Universitas Terbuka

Sudjana, Nana \& Ibrahim. 2012. Penelitian dan Penilaian Pendidikan (Cetakan ke7). Bandung: Sinar Baru Algensindo

Sudrajat, A. 2008. Pengembangan Bahan Ajar Materi Pembelajaran PAI. Makalah disajikan dalam Workshop Bimbingan Teknis Penguatan KTSP SMP bagi Tim Pengembang Kurikulum/Verfikator Propinsi, di Hotel Graha Dinar, Cisarua Bogor pada Maret 2008

Sungkono, 2012. Pengembangan Instrument Evaluasi Media Modul Pembelajaran. Yogyakarta: Fakultas Ilmu Pendidikan UNY

Supriyanta, Eko Yuli. 2015. Pengembangan Media Komik untuk Mata Pelajaran Ilmu Pengetahuan Sosial Tentang Sejarah Persiapan Kemerdekaan Indonesia pada Kelas $V$ SD Muhammadiyah Mutihan Wates Kulon Progo. Skripsi. Yogyakarta: Program Studi Pendidikan Guru Sekolah Dasar Universitas Negeri Yogyakarta.

Tim Dirjen GTK. 2019. Buku Pegangan Pembelajaran Berorientasi Pada Keterampilan Berpikir Tingkat Tinggi. Jakarta: Kementerian Pendidikan dan Kebudayaan

Tohirin. 2001. Psikologi Belajar Pendidikan Agama Islam. Pekanbaru: Raja Grafindo Persada

Ulya, H. dan Rahayu,R. 2018. Uji Kelayakan Perangkat Pembelajaran OpenEnded Berbasis Etnomatematika Ditinjau dari Gaya Kognitif Siswa. Journal of Medives, 2 (2), 183-194

Winkel. 2009. Psikologi Pengajaran. Yogyakarta: Media Abadi 
Jurnal Ilmu Sosial dan Pendidikan

http://ejournal.mandalanursa.org/index.php/JISIP/index

Terakreditasi Peringkat 5 (No. SK: 85/M/KPT/2020)

Widodo, C. \& Jasmadi. 2008. Buku Panduan Menyusun Bahan Ajar. Jakarta: PT. Elex Media Komputindo.
Vol. 5. No. 1 Januari 2021

p-ISSN: 2598-9944 e- ISSN: 2656-6753 